7 - ORIGINAL ARTICLE

\title{
Increase of gastric area and weight gain in rats submitted to the ingestion of gasified water ${ }^{1}$
}

Aumento de área gástrica e ganho de peso em ratos submetidos à ingestão de água gaseificada

\section{José Roberto Ferreira Santiago ${ }^{2}$, Shoiti Kobayasi ${ }^{3}$, José Mauro Granjeiro ${ }^{4}$}

1. Dissertation presented to the post-graduation program of Surgery of the Faculty of Medicine, Botucatu - UNESP.

2. Post-graduated student of Surgery of the Faculty of Medicine, Botucatu - UNESP. jrfsantiago@uol.com.br

3. Professor of the Department of Surgery and Orthopedics of the Faculty of Medicine, Botucatu - UNESP. shoiti@fmb.unesp.br

4. Associated Professor of the Department of Biological Sciences (Biochemistry) of the Faculty of Odontology, Bauru - USP. jomagra@ fob.usp.br

\footnotetext{
ABSTRACT

PURPOSE: Due to the progressive increasing in the use of gasified drinks and weight gain in the Brazilian population, in addition to the fact that carbonic gas is present in all soft drinks, an experimental study was conducted using rats as the subject to investigate the effects of gasified water in the hydric ingestion and food intake, weight gain, gastric area, blood sugar, hematocrit, and hemoglobin.

METHODS: Four groups of 12 rats were studied for 36 days while receiving the following daily diet, four times per day: Group 1 - 35g/day of rat food "ad libitum" and 20ml of non-gasified water; Group $2-35 \mathrm{~g} /$ day of rat food "ad libitum" and $20 \mathrm{ml}$ of gasified water; Group 3 $10 \mathrm{~g} /$ day of rat food "ad libitum" and $20 \mathrm{ml}$ of non-gasified water; and Group $4-10 \mathrm{~g} /$ day of rat food "ad libitum" and $20 \mathrm{ml}$ of gasified water.

RESULTS: The results showed that the animals submitted to the treatment with gasified water (Groups 2 and 4), presented a larger volume of hydric ingestion and significant increase of the gastric area $(\mathrm{p}<0,001)$. In group 2 , the food intake and the weight gain were significant $(\mathrm{p}<0,01)$. Blood sugar, hematocrit and hemoglobin data didn't show significant alterations among the studied groups.

CONCLUSION: The authors of this study concluded that gasified water favored the hydric ingestion, food intake, and weight gain, as well as expanded the gastric area.

Key words: Weight gain. Gasified water. Carbonic gas. Gastric area.
}

\section{RESUMO}

OBJETIVO: Em virtude do aumento progressivo da utilização de bebidas gaseificadas e do ganho de peso na população brasileira, e sabendo-se que os refrigerantes têm no gás carbônico 
um fator em comum, planejou-se um estudo experimental em ratos para investigar os efeitos da água gaseificada na ingestão hídrica e alimentar, ganho de peso, área gástrica, glicemia, hematócrito e hemoglobina.

MÉTODOS: Foram constituídos 4 grupos de 12 ratos acompanhados por 36 dias. Ao Grupo-1 foi oferecido $35 \mathrm{~g} /$ dia de ração "ád libitum" e $20 \mathrm{ml}$ de água não gaseificada em 4 períodos diários, ao Grupo-2 foi oferecido 35 g/dia de ração "ad libitum" e $20 \mathrm{ml}$ de água gaseificada em 4 períodos diários, ao Grupo-3 foi oferecido $10 \mathrm{~g} /$ dia de ração "ád libitum" e $20 \mathrm{ml}$ de água não gaseificada em 4 períodos diários e ao Grupo-4 foi oferecido $10 \mathrm{~g} /$ dia de ração "ad libitum" e 20 $\mathrm{ml}$ de água gaseificada em 4 períodos diários.

RESULTADOS: Os resultados identificaram que os animais que foram submetidos ao tratamento com água gaseificada (Grupo-2 e Grupo-4), apresentaram um maior volume de ingestão hídrica e aumento significativo da área gástrica $(\mathrm{p}<0,001)$, no Grupo-2 a ingestão alimentar assim como o ganho de peso foi significativo $(\mathrm{p}<0,01)$, os dados de glicemia, hematócrito e hemoglobina não tiveram alterações significativas entre os grupos estudados.

CONCLUSÃO: Nas condições em que foi realizado este experimento, concluímos que a água gaseificada favoreceu a ingestão hídrica e alimentar, o ganho de peso e o aumento da área gástrica.

Descritores: Ganho de peso. Água gaseificada. Gás carbônico. Área gástrica.

\section{Introduction}

The excessive weight classification is based on the Body Mass Index (BMI) provided by the World Health Organization (WHO, 1997). This criterion indicates that adults who follow in the $25 \mathrm{~kg} / \mathrm{m}^{2}-29,9 \mathrm{Kg} / \mathrm{m}^{2}$ zone are ranked as above average and individuals whose weight is $30 \mathrm{~kg} / \mathrm{m}^{2}+$ as obese ${ }^{1}$.

The occurrence of excessive weight in the population significantly increased during the last decades among adults and children, not only in the developed countries but also in the developing ones. European and American studies demonstrate that there are nowadays a higher incidence of people with weight above average than in the past. These studies demonstrate that the greatest responsibles for this situation are the current diets, which are enriched with carbohydrates and high amounts of fat ${ }^{2-4}$.

The obesity, compared to the general population, is associated to the increase of risk factors for a variety of diseases, as well as death ${ }^{5}$. The obesity leads to higher risk for health 
problems such as cardiovascular illness, arterial hypertension, vascular accidents in the brain, breast and prostate cancer, joint problems, diabetes, gout, hiperlipidaemia, breathing difficulties, gastrooesophageal, among others that can put the health of the patient at risk ${ }^{6,7}$.

There are some factors that can be considered the cause of the excessive weight growth; however, they can not be easily isolated. Some examples are the genetic factors and cultural context where the individual grows up and lives. It is believed that differences such as the accumulation of body fat (such as generalized, android, gynoid, or visceral), the quality and quantity of consumed food, the cultural and family contexts, and the life style of an individual can play an important role in the predisposing factor of excessive weight gain. The appetite also seems to be the main factor related to the biologic regulation of the excessive weight and eating behavior. Moreover, the profile of the eating activity is directly reflected on both the physiologic and periferic biochemicals that add to the alterations in the body weight ${ }^{4,8,9}$.

Advances in the genetic knowledge on obesity have been increasing during the last years; however, the existing information about the environmental and behavioral influences on the process that promote human obesity is still scare. The excessive weight is not an isolated process. There is a broad list of involved factors such as eating pattern, environmental influences, food conditioning, metabolic resting level, thermogenisis of dietetic induction, and a wide list of possible "environmental candidates" yet to be researched ${ }^{10}$.

Gazed drinks are spread among every socio-economic levels, and play an important environmental role in the eating behavior of the people. This fact has been established in a study conducted in Mexico City, where it was concluded that $82.3 \%$ of the population consumed soft drinks in a daily basis resulting in an average of 0.6liter/day and 3.5liter/week, independent of the educational level of the people ${ }^{11}$. 
Some authors, when analyzed the effects of soft drinks sweetened with aspartame or sucrose, observed that the consume of these drinks increased significantly the ingestion of macronutrients in the diet ${ }^{12}$. These authors suggested that the ingestion of drinks sweetened with aspartame do not minimize the ingestion of other food and can promote a larger ingestion of nutrients during the following days.

The risks and damages associated with the consumption of soft drinks are varied. Some of the problems are dental diseases, change in the mineral metabolism, peptic acid disease, increase of risk factors for cardiovascular diseases, and effects in the Central Nervous System. Such risk factors are related to the use of caffeine, among others. It is known than, that the excessive consumption of soft drinks can represent a public health problem ${ }^{13}$.

Between 1947 and 1997, there was a significant increase in the consumption of gasified drinks as a result of the aggressive advertising related to the easy access to these products. The gasified drinks contain enormous amounts of sugar, which leads to an epidemic of weight gain, substituting the milk, which contributes to high levels of osteoporosis, dental problems, and calculus. Moreover, other additives contained in such drinks can lead to heart diseases, insomnia, behavior problems, allergic reactions, as well as a higher tendency of developing cancer ${ }^{14}$.

The analysis of the literature during the past 10 years revealed that there are some genetic and environmental factors involved in the excessive gain of weight, specially linked to the fact that obesity represents a potential risk to the individual, in addition to the role that the gasified drinks plays in the excessive weight and other disorders. On the other hand, it has not been clarified yet if the gas contained in the soft drinks interfere with the metabolism of an individual leading either to excessive weight or eating behavior. In this view, there is neither an analysis of the role that the quantity of gas contained in these drinks plays in the problem, nor there is an 
analysis of the possible effects of its real interference in the histologic and anatomic metabolic processes.

The metabolic tracks of the synthesis of both carbohydrates and lipideos, present enzymatic processes that require $\mathrm{CO}_{2}$ as one of the substrates. This is the case of the pyruvate

carboxylase (PC) and acetyl CoA carboxylase, respectively ${ }^{15}$. As a result, it is important to investigate the carbonic gas factor, largely diffused in liquid food material, in the variables that interfere with the metabolism and weight excess.

On the other hand, diets restricted in calories in conjunction to physical exercises are prescribed to treat individual with excessive weight problem ${ }^{8}$. A clinical observation of obese patients under an ambulant treatment suggests that the patients that indiscriminately used gasified drinks presented an inadequate response to the dietetic treatment. These patients quickly regained their previous weight, as soon as they abandoned the treatment, in contrast to the patients that did not consume gasified drinks. In this view, the present study had as its main objective, to investigate the effects that gasified water have on rats. The study thus, was designed to prescribe two divergent diets to different groups of rats: one with restricted amount of food and other with non-restricted food. The parameters of the present study was the hydric and food ingestion, weight of the animals, gastric area measured through contrasted XR, and lab exams of glicemia, hematocrit, and hemoglobin. The choice to use gasified water was based on the fact that all the soft drinks as well as the gasified water have the carbonic gas as a common factor.

\section{Methods}

Forty-eight 3-months-old Wistar rats, variety albinos, weighting an average of $386 \mathrm{~g}$, were used in this experiment. The rats were randomly separated in 4 groups of 12 rats each and grouped accordingly to the experimental design (Figure 1). Thus, 20ml of water (gasified or 
regular, depending on the experimental design) were offered in a daily basis during four periods per day: $10 \mathrm{am}, 1 \mathrm{pm}, 4 \mathrm{pm}$, and $7 \mathrm{pm}$, allowing 40 minutes for ingestion. The water than was taken for quantification. Also, 35g of rats-food were offered to each one of the animals in groups G1 and $\mathrm{G} 2$, and $10 \mathrm{~g}$ to groups $\mathrm{G} 3$ and $\mathrm{G} 4$ at $7 \mathrm{pm}$, during 36 days, period which lasted the experiment. Likewise the water, the food was also taken for quantification at the end of a longer period of 24 hours. All rats were weighted before and after every six days during the procedure. Following this period, each animal was sedated in order to receive baritado contrast in the stomach through an oro-gastric catether and than, conducted a radiologic exam. Both the collection and processing of the material for the anatomopathologic and lab exams were realized after the euthanasia of the animals was done. The animals in groups 1,2, 3, and 4 were randomly evaluated at corresponding times.

\begin{tabular}{|c|c|c|}
\hline & & 2 \\
\hline G1 - (Diet 35g/day) & $\mathrm{n}=12$ & 36 days \\
\hline G2 - (Diet 35g/day) & $\mathrm{n}=12$ & 36 days \\
\hline G3 - (Diet $10 \mathrm{~g} /$ day $)$ & $\mathrm{n}=12$ & 36 days \\
\hline G4 - (Diet $10 \mathrm{~g} /$ day $)$ & $\mathrm{n}=12$ & 36 days \\
\hline \multicolumn{2}{|c|}{ 80ml/day-Regular water (G1and G3) } & EXR and euthanasia \\
\hline \multicolumn{2}{|c|}{$80 \mathrm{ml} /$ day-Gasified water(G2 and $\mathrm{G} 4)$} & $\mathrm{n}=$ Number of animals \\
\hline
\end{tabular}

FIGURE 1 - Experimental design.

The methodological procedure was submitted to the analysis of the Ethics Committee in Research (CEP) of the USC ( Bauru-SP) and was supported by the Ethics in Experimental Research Committee of the UNESP, Botucatu-SP (protocol 171). Both committees approved the procedure previously to the experiment. 
The animals were individually kept in metabolic cages so the following attributes could be studied: hydric ingestion, food ingestion, weight, gastric area, glicemia, hematocrit, and hemoglobin. The gastric area was evaluated through the baritado gastroduodenal radiologic exam of the animals after a period of 12 hours of fastening. The animals were sedated with intermuscular 25 X 5 needles containing $5 \mathrm{mg} / \mathrm{kg}$ per body weight of Diazepam in the back of their upper lags. After a period of 30 minutes the animal was put in a dorsal position on a straining instrument with the film attached to the dorsal region. The polyethylene catheter (size 8, $15 \mathrm{~cm}$ ) was introduced through the mouth and placed in the stomach of the animals ${ }^{16} .7 \mathrm{ml}$ of a previously prepared solution of $2 \mathrm{~g}$ of barium sulfate diluted in $3 \mathrm{ml}$ of water was slowly injected through the oro-gastric catether. This technique was modified as suggested by Gershon-Cohen and Shay ${ }^{17}$. The XR machine had its ray's exit positioned $25 \mathrm{~cm}$ from the film in a perpendicular position. The machine was activated 1 minute after the injection of the $40 \mathrm{KV}, 15 \mathrm{~mA}$, and 8 pulses as exposition time ${ }^{18}$. The radiologic films were digitized by a digitizer, so that a software programmed to analyze "pixels" could analyze them. The software adds the analyzed values using as basis for transformation $0,000041 \mathrm{~cm}^{2}$, which corresponds to one "pixel". The measuring values of the gastric areas in the $\mathrm{XR}$ are approximated, that is, the error margin have similar equivalence.

When the radiologic exam was done, the animals were sedated with ethyl ether causing the euthanasia through hemorrhage, which leads to a cardiac puction ${ }^{19}$. The blood obtained from the cardiac puction was collected in heparinized tubes that were individually identified according to each animal allowing the glicemia, hematocrit, and hemoglobin procedure.

Statistical analysis

An Analysis of Variance of the medium (x) and standard deviation (s) was conducted for every attribute of each group. The median value of each group was used to build the analysis of 
the result ${ }^{20}$. For each hypothesis, the statistical values of $\mathbf{F}$ and $p(p>0.05)$ were calculated. In addition, the Tukey method was applied to measure the minimum significant difference ( $m s d$ ), $?=0.05$, among the contrasts between pairs of median. A tendency to significance was observed when $0.05<p<0.10$ ( $p$ is the probability of erroneously concluding based on the significance).

In addition, a simplified statistical analysis, which compared the effects of water type on each specific diet, was used to measure the weight of the animals, since the obtained results were considered peculiar. The groups that received a "free diet" presented a behavior totally different from the groups with restricted diet. As a result, a paired $t$ test was conducted to compare G1 to G2, considering seven periods for weight evaluation. The same procedure was done to compare G3 to G4.

\section{Results}

The group that was treated with gasified water and a free diet of 35g/day of food (G2) had a significantly higher consume of food (Table 1) and a progressive weight gain in relation to the other groups (Figure 2).

TABLE 1 - Median values of the daily ingestion of food in grams (g/day) and respective standard deviation in the experimental groups. ${ }^{\mathrm{a}} \mathrm{n}=12$ for every group ${ }^{\mathrm{d}<\mathrm{b}<\mathrm{c}} \mathrm{F}=12.88$ and $\mathrm{p}<0,01$ : $\mathrm{G} 4=\mathrm{G} 3<\mathrm{G} 1<\mathrm{G} 2$.

\begin{tabular}{lc}
\hline \multicolumn{1}{c}{ ANIMAL GROUPS $^{\mathrm{a}}$} & FOOD \\
\hline G1 - (Free diet and regular water) & $23.03\left({ }^{ \pm} 1.38\right)^{\mathrm{b}}$ \\
G2 - (Free diet and gasified water) & $25.13\left({ }^{ \pm} 1.56\right)^{\mathrm{c}}$ \\
G3 - (Restricted diet and regular water) & $9.92\left(\left(^{ \pm} 0.06\right)^{\mathrm{d}}\right.$ \\
G4 - (Restricted diet and gasified water) & $9.86\left({ }^{ \pm} 0.10\right)^{\mathrm{d}}$ \\
\hline
\end{tabular}




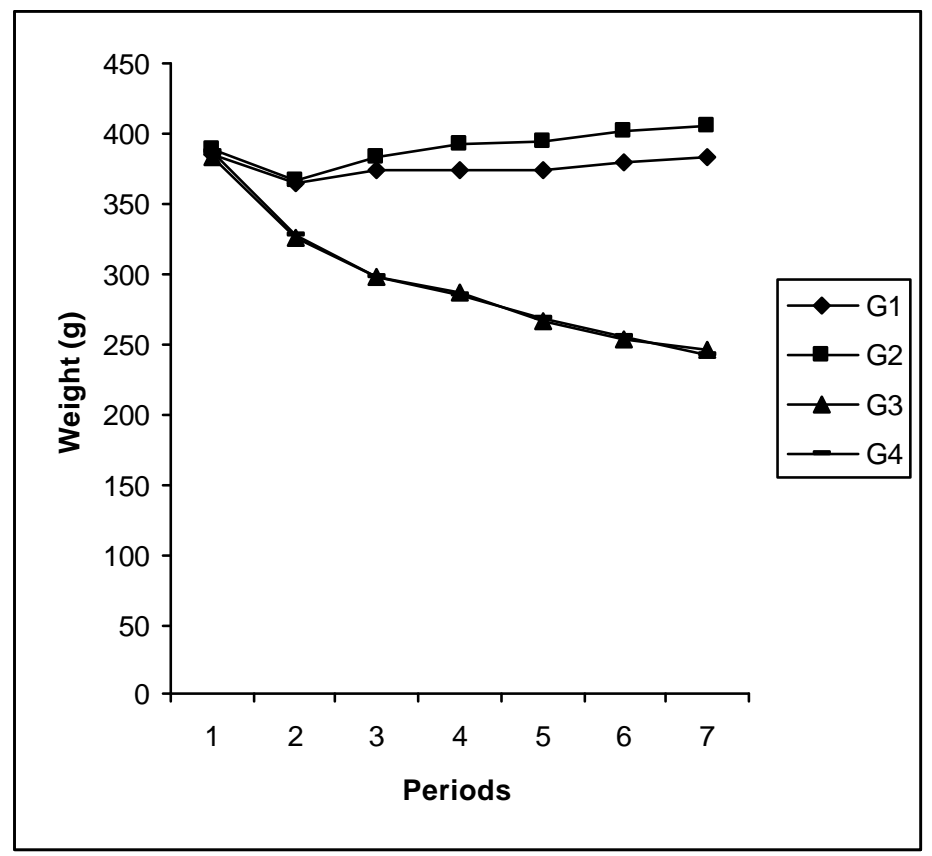

FIGURE 2 - Animals' weight in grams. Median values of each evaluation period. G1 (free diet and regular water), G2 (free diet and gasified water), G3 (restricted diet and regular water), and G4 (restricted diet and gasified water). Each evaluation period $=6$ days. $\mathrm{n}=12$ in each group $t=4.25$ and $\mathrm{p}<0,001: \mathrm{G} 1<\mathrm{G} 2$.

The experimental groups that were drinking gasified water (G2 and G4) presented a higher intake of water (Table 2) and significant expansion of their stomach size in relation to the animals that did not drink gasified water (Figure 3). Naturalistic observations of the contrasted radiologic exam of the stomach of the animals demonstrate that the gastric areas of the animals in groups G2 and G4 were bigger than the animals in groups G1 and G3 (Figure 4).

TABLE 2 - Median values of the daily ingestion of water in milliliters $(\mathrm{ml} / \mathrm{day})$ and respective standard deviation in the experimental groups. ${ }^{a} n=12$ for every group ${ }^{\mathrm{d}<b<e<c} \mathrm{~F}=32.62$ and $\mathrm{p}<0,001$ : $\mathrm{G} 3<\mathrm{G} 1<\mathrm{G} 4<\mathrm{G} 2$.

\begin{tabular}{ll}
\hline \multicolumn{1}{c}{ ANIMAL GROUPS $^{\mathrm{a}}$} & WATER \\
\hline G1 - (Free diet and regular water) & $42.20( \pm 5.09)^{\mathrm{b}}$ \\
G2 - (Free diet and gasified water) & $59.47( \pm 2.72)^{\mathrm{c}}$ \\
G3 - (Restricted diet and regular water) & $28.25( \pm 1.64)^{\mathrm{d}}$ \\
\hline
\end{tabular}




G4 - (Restricted diet and gasified water) $\quad 56.02\left({ }^{ \pm} 2.14\right)^{\mathrm{e}}$

FIGURE 3 - Stomach area: average of the experimental groups in $\mathrm{cm}^{2}$. G1 (free diet and regular water), G2 (free

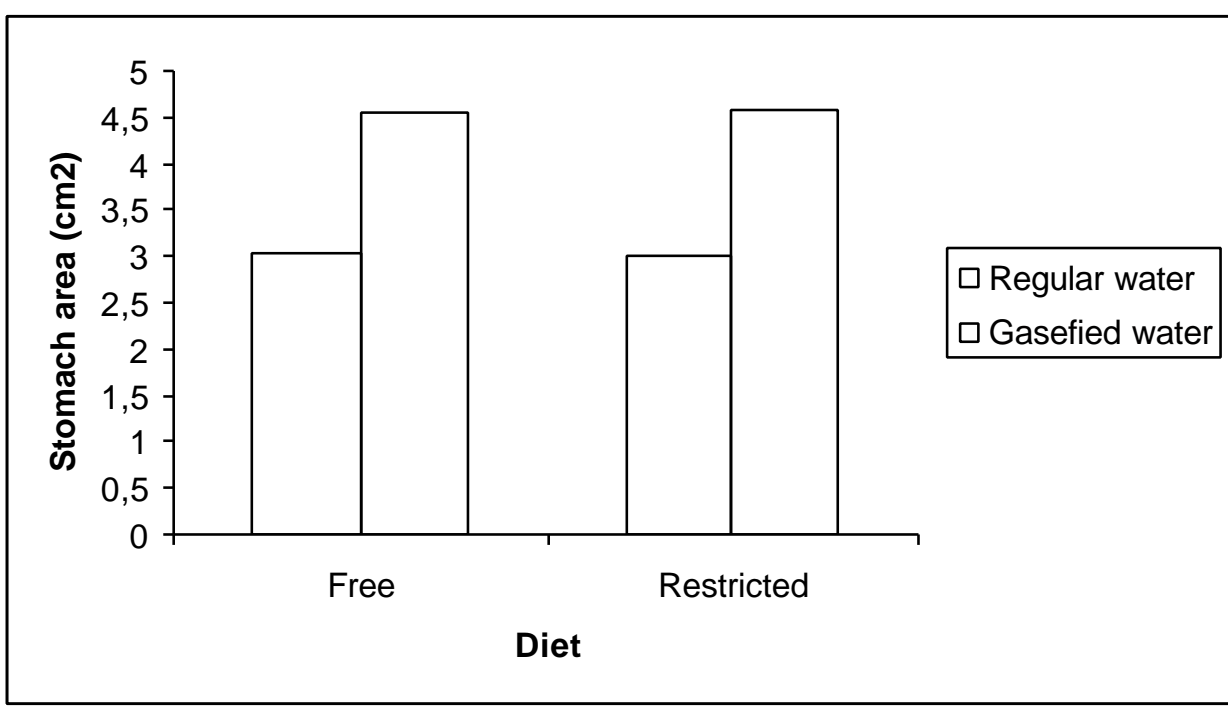

diet and gasified water), G3 (restricted diet and regular water), and G4 (restricted diet and gasified water). $\mathrm{n}=12$ in each group $\mathrm{F}=116.37$ and $\mathrm{p}<0,001: \mathrm{G} 1=\mathrm{G} 3<\mathrm{G} 2=\mathrm{G} 4$. 
G1

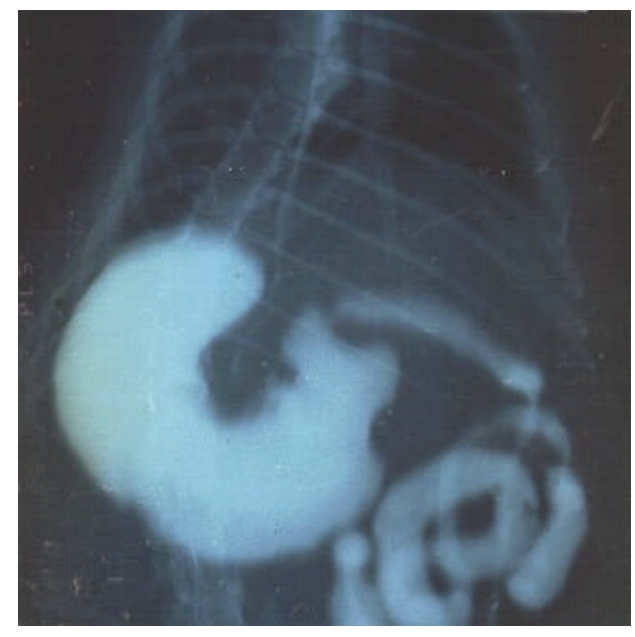

G3

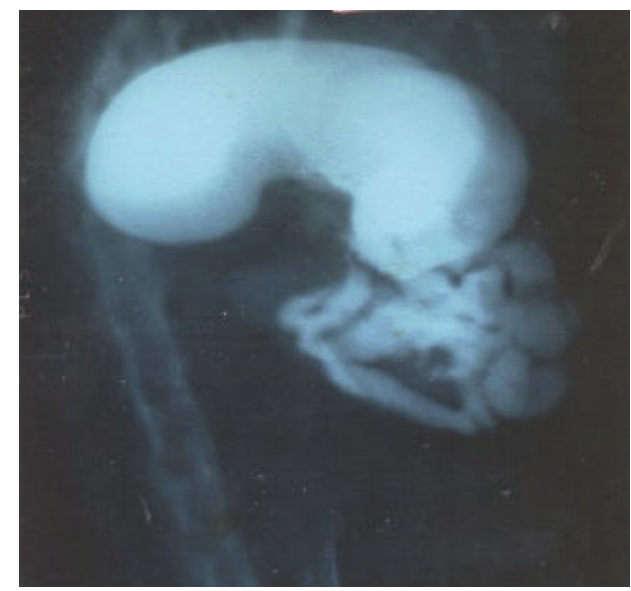

G2

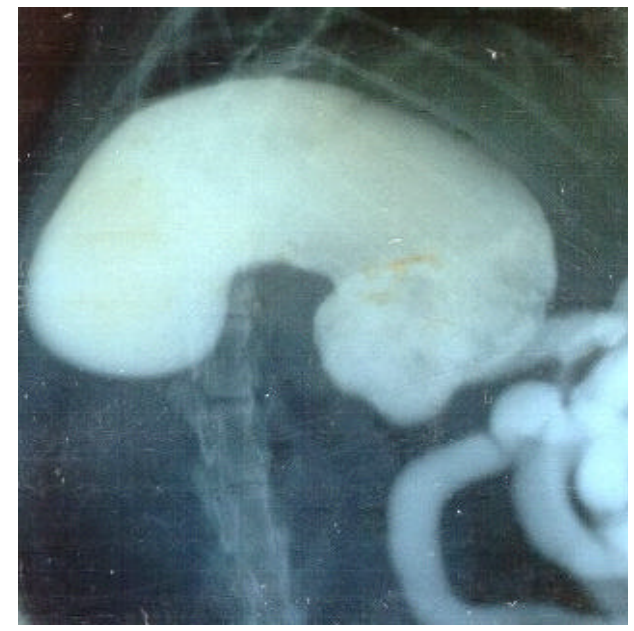

G4

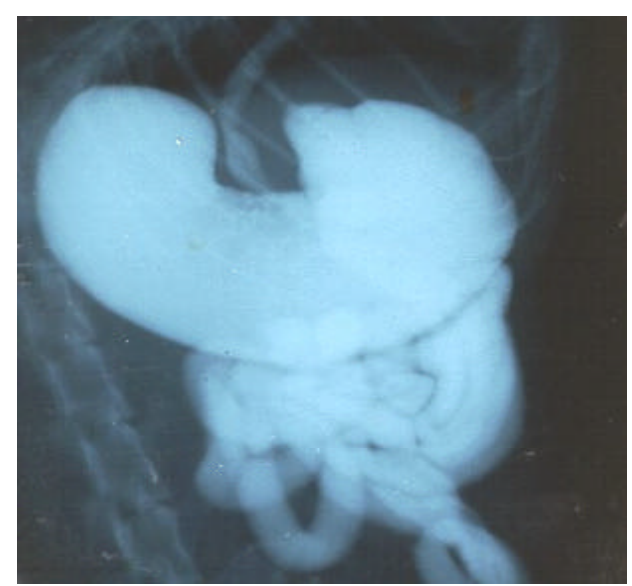

FIGURE 4 - Contrasted stomach XR of rats with films realized 1 minute after the bario sulfate prescription. G1 (free diet and regular water), G2 (free diet and gasified water), G3 (restricted diet and regular water), and G4 (restricted diet and gasified water).

The glicemia, hematocrit and hemoglobin data obtained after a period of 12 hours of fastening, were analyzed in the morning accordingly to each group of animals. It was concluded, that there were no significant changes between the animals that ingested different types of water; however, they shrunk in the animals that had water restriction.

\section{Discussion}


In the United States, $31 \%$ of the men and $24 \%$ of the women have their weight classified as above the ideal ${ }^{21}$. The obesity raises the risk for mortality, placing the obese people in a more vulnerable position to develop cardiovascular illnesses, diabetes, hypertension, breathing problems, digestive illnesses, cerebral vascular accidents, arthritis, among others. Still in the United States, $24 \%$ of men and $40 \%$ of women follow a restricted diet, and all the evidences clearly show that the efforts to lose weight which involve modifications in the diet and physical activities are more beneficial than harmful to the health of the individuals ${ }^{22}$. Even the non-obese population has to make efforts such as controlling the quality of their eating and doing physical exercises regularly in order to conserve their weight in an ideal level.

Both the hunger and weight are controlled by a series of biological factors such as the activities of the hypothalamic centers, insulin use of the glucose in the blood, metabolic levels, number and size of the adipose cells, genetic presdipositions related to a series of environmental factors such as the cultural, ethnic, and eating traditions that are related to the preferences acquired through conditioning and modeling. Some examples of these are eating late and/or eating while doing another activity ${ }^{10}$.

In this view, this study was designed to analyze the environmental factors that has their roots in the eating habits, that is, the use of soft drinks. The main focus was on the carbonic gas, which is a common element to all soft drinks, and there is no work in the literature that links this substance to the eating habits.

The research was designed to use rats as the experimental animals because they are small and easily manipulated, which makes it possible to use them in great number and at the same time, without the need of a great physical space. In spite of these characteristics, the rats are highly resistant animals that excuse the need of sophisticated materials for their maintenance. 
Finally, the literature does not present an empirical work using the gasified water in experimental study with animals, reason why we decided to use it in this experiment, considering the fact that it is a substance present in all kinds of soft drink.

Four groups of twelve rats were employed in this experiment in order to allow observations of both the hydric and feeding ingestions, as well as their weight. In a previous pilot study, it was noted that the volume of the ingested gasified water was high, so that it was hypothesized that increasing the volume of the gasified water ingested by the animals would change their gastric morphology. The choice to measure the gastric area through the radiologic exam was made based on the fact that the metabolic tracks of the synthesis of the carbohydrate require $\mathrm{CO}_{2}$ as one of the subtracts, as it is the case of the pyruvate carboxylase. In this view, we thought that it was appropriate to investigate if the glicemia levels could also be altered due to the $\mathrm{CO}_{2}$ absorption. In the same way, the hematocrit and the hemoglobin were quantified since they function as transporting vehicles of $\mathrm{CO}_{2}$ in the blood.

Experimental groups receiving a restricted diet were added to the experiment because we previously wanted to investigate the effects of the gasified water, independently of the excessive diet. The sequence of the experimental timing, which was previously conducted in a pilot study, facilitated the quantification of the methodology and helped to make a pattern of the applied procedures, favoring an adequate experimental protocol.

The ingestion of rats-food in the animals that utilized gasified water and received a free diet (35g/dia "ad libitum") was observed during a period of six weeks. There was no significant increase during the first three weeks, but beginning from the fourth week, the gain was significant. The gasified water ingested in a larger volume, could have contributed to the elevation of the food ingestion, since it was an independent factor of the volume of food in the 
enlargement of the gastric area. This situation could have provoked hunger or even decreased the satiation.

The hunger sensation associated to the negative energetic balance represents a great obstacle to the weight loss and obesity control. The hunger suppression through behavioral, dietetic, and pharmacological changes has been the primary measure in the obesity therapy. The lack of the therapeutic manipulation of the hunger partly results from the lack of comprehension of the property of the aliments and their role in modifying this sensation ${ }^{23-24}$.

The term hunger refers to a strong desire for food. The term appetite is utilized in the same way, except for it implicates in the desire for certain types of food. The satiation can be seen as a process that brings the suspension of food, at the same time that satiety can be considered as events that originated from the consume of food and serve to suppress the hunger 25

Hunger and satiety are the main sensorial factors that regulate the volume and frequency of eating. On the other hand, during the experiment, it was observed that the time of intake of the gasified water was clearly small since the start. With or without food, the rats consumed big volumes of gasified water as if they were dependents of it, becoming sleepy during the periods following its ingestion and irritable during the periods that there was no gasified water available. It was not possible to quantify this behavioral data; however, both the volume of the gasified water ingestion and the gastric area are clearly larger (above 50\%) independently of the diet.

The gasified water presents a low satiation level in relation to the regular water. The animals that utilized the gasified water drank it in a higher proportion in relation to the animals that drank the regular water. Therefore, it is probable that this factor provoked a bigger ingestion of volume of food in the groups that had gasified water and a free diet of $35 \mathrm{~g} / \mathrm{day}$ "ad libitum" (G2). 
Recently, it was observed that the stomach synthesizes an orexygen called Ghrelin in response to a period of fastening ${ }^{26}$. This substance is a peptic cerebro intestinal regulator, which was isolated and described by Kojima ${ }^{27}$ as being the first stimulating sign of the oriunde appetite of the stomach.

The peripheral administration of the Ghrelin stimulates the increasing of food ingestion in rats leading to a consequent weight gain ${ }^{28}$. Moreover, its action in the central nervous system is made through the agonistic action with the neuropeptide $\mathrm{Y}$, hypothalamic orexygen ${ }^{29}$. In this view, it is possible that the irritability observed in the animals that consumed the gasified water could be related to the hunger state provoked by the gastric enlargement. Follow up studies are necessary to establish a correlation between a gastric enlargement, caused by the use of gasified water, and the Ghrelin seric levels.

The groups that were treated with a restricted diet (10g/day "ad libitum") presented a significant decrease in the glicemia, hematocrit and hemoglobin quantification. The use of different types of water did not interfere with the process, in the same way that the observed deficit is only due to the restriction of the diet.

\section{Conclusion}

We can conclude that the gasified water increased the volume of hydric ingestion, volume of food ingestion, the weight, and the gastric area of the rats under the conditions in which this experiment was consumed. The consume of gasified water did not interfere however with the seric levels of glicemia, hematocrit, and hemoglobin.

\section{References}


1. Bray GA. Pathophysiology of Obesity. Am J Clin Nutr 1992; 55 (suppl): 488-94.

2. Escrivão, MAMS, Pliveira FLC, Lopez FA, Taddei, JAAC. Obesidade na infância e na adolescência. J Pediatr 2000; 76 (supl 3): 305-10.

3. Kluthe R, Scubert A. Obesity in Europe. Ann Intern Med 1985; (103): 1037-42.

4. Stunkard AJ, Wadden TA. Restrained eating and human obesity. Nutr Rev 1990; 48(2):7886.

5. Heraief E. The contribution of epidemiology to the definition of obesity and its risk factors. Ther Umsch 1989; 46(5): 275-80.

6. Garfinkel L. Variation in mortality by weight among 750000 normal women. J Chron Dis 1979; (32): 563-76.

7. De Fronzo RA, Ferrannini E. Insulin resistence. A multifaceted syndrome responsible for NIDDM, obesity, hypertension, dyslipidemia and atherosclerotic disease. Diabetes Care 1991; 14(3): 173-94.

8. Bouchard C, Perusse L, Heredity and body fat. Ann Rev Nutr 1988; 8:258-77.

9. Blundell JE Obesidade: teoria e terapia. In: Psicologia fisiológica. Rio de Janeiro: Zahar; 1976. p. 63-76.

10. Faith MS, Johnson SL, Allison DB. Putting the behavior into the behavior genetics of obesity. Behav Genet 1997; 27(4): 423-39.

11. Maupome-Carvantes G, Sanchez-Reyes V, Laguna-Ortega S, Andrade-Delgado LC, Bonilla-Calderon JD. Patrón de consumo de refrescos en una población mexicana. Salud Publica Mex 1995; 37(4): 323-8.

12. Lavin JH, French SJ, Read NW. The effect of sucrose and aspartame-sweetened drinks on energy intake, hunger and food choise of female, moderately restrained caters. Int J Relat Metab Disord 1997; 21(1): 37-42.

13. Amato D, Maravilla A, Garcia-Contreras F, Paniagua R, Los refrescos y la salud. Rev Invest Clin 1997; 49(5): 387-95.

14. Jacobson MF. Liquid candy: how soft drinks are harming americans'health. [Cited 2001 Apr] Available from: URL http://www.cspinet.org/sodapop/liquid_candy/htm

15. Lehninger AL, Nelson DL, Cox MM. Princípios de Bioquímica, $2^{\mathrm{a}}$ ed São Paulo: Sarvier, 1995.

16. Machella TE, Griffith JQ. Jr. The digestive system. In: Farris JE, Griffith JQ. The rat in laboratory investigation. $2^{\text {nd }}$ ed New York: Hafner; 1963. p. 166-80. 
17. Gershon-Cohen J, Shay H. Radiologic considerations in gastro-intestinal examination of rat. In: Farris JE, Griffith JQ. The rat in laboratory investigation. $2^{\text {nd }}$ ed. New York: Hafner, 1963: 421-33.

18. Pendergrass EP, Griffith Jr. JQ. Radiologic considerations. In: Farris JE, Griffith JQ. The rat in laboratory investigation. $2^{\text {nd }}$ ed New York: Hafner; 1963. p. 421-33.

19. Souza NL. Eutanásia. In: De Luca RR. et al. Manual para técnicos em bioterismo. $2^{\mathrm{a}}$ ed São Paulo: H. A. Rothschild; 1996. p. 171-7.

20. Curi PR. Metodologia e análise da pesquisa em Ciências Biológicas. $2^{\mathrm{a}}$ ed Botucatu: Tipomic, 1978.

21. Brownell KD, Rodin J. The dieting maelstrom. Is it possible and advisable to lose weight. Am Psychol 1994; 49 (9): 781-91.

22. French SA, Jeferry RW. Consequences of dieting to lose weight: effects on physical and mental health. Health Psychol 1994; 13(3): 195-212.

23. Prentice AM, Poppitt SD. Impotance of energy density and macronutrients in the regulation of energy intake. Int J Obes Relat Metab Disord 1996; 20: 518-23.

24. Kirkmeyer SV, Mattes RD. Effects of food attributes on hunger and food intake. Int J Obes Relat Metab Disord 2000; 24(9): 1167-75.

25. Blundell JE. Hunger, appetite and satiety-constructs in search of identities. In: Turner M. Nutrition and Lifestyles. London: Applied Science Publish; 1949. p. 21-42.

26. Inui A. Ghrelin: an orexigenic and somatotrophic signal from the stomach. Nature 2001; 2(8): 551-60.

27. Kojima M, Hosoda H, Matsuo H, Kangawa $\mathrm{K}$, Ghrelin is a growth-hormone-releasing acylated peptide from stomach. Nature 1999; (402): 656-60.

28. Tschöp M, Smiley DL, Heiman ML, Ghrelin induces adiposity in rodents. Nature 2000; (407): 908-13.

29. Nakazato MA role for ghrelin in the central regulation of feeding. Nature 2001; (409): 194-8.

Correspondence:

José Roberto F. Santiago

Av. Mário Ranieri, 445 , casa $\mathrm{H} 7$

17015-430 Bauru - SP

Tel: (014) 3236-4639

irfsantiago@uol.com.br 
Data do recebimento: 27/02/2004

Data da revisão: 16/03/2004

Data da aprovação: 01/04/2004

Conflict of interest: none

Financial source: none

\section{How to cite this article:}

Santiago JRF, Kobayasi S, Granjeiro JM. Increase of gastric area and weight gain in rats submitted to the ingestion of gasified water. Acta Cir Bras [serial online] 2004 May-Jun;19(3). Available from URL: http://www.scielo.br/acb. [also in CD-ROM]. 